\author{
Loyalitas Kreativitas \\ Aldi Masyarakat Kreatif
}

P-ISSN 2722-2101, E-ISSN 2722-4201

Program Studi Ekonomi Manajemen Universitas Pamulang

Jurnal LOKABMAS Kreatif Vol.02,No.01,Maret 2021 Hal. 48-54

Email:jurnalkreatif.manajemen@gmail.com

\title{
PEMANFAATAN TEKNOLOGI DALAM MEMOTIVASI PROSES KBM YANG KREATIF DAN INOVATIF KEPADA SISWA-SISWI SMK MUHAMMADIYAH PARAKAN PAMULANG TANGERANG SELATAN
}

\author{
Ana Septia Rahman, Nindie Ellesia, Lismiatun, \\ Abdul Azis, Eka Rahim \\ Dosen Prodi Manajemen Fakultas Ekonomi Universitas Pamulang \\ Email : dosen01709@unpam.ac.id, dosen02292@unpam.ac.id, dosen01460@unpam.ac.id, \\ dosen02241@unpam.ac.id, dosen01736@unpam.ac.id
}

\begin{abstract}
ABSTRAK
Tujuan dari Kegiatan Pengabdian Kepada Masyarakat adalah untuk melaksanakan salah satu Tri Darma Perguruan Tinggi khususnya di Universitas Pamulang.Selain itu diharapkan dengan pengabdian kepada masyarakat tersebut keberadaan perguruan tinggi dapat memberikan kontribusi kepada pengembangan penerapan keilmuan kepada masyarakat.

Metode yang digunakan pada pengabdian kepada masyarakat ini penyampaikan materi secara verbal dalam pelaksanaan ini materi dalam penyuluhan berisi tentang bagaimana cara untuk mengetahui manfaat lain dari teknologi seperti komputer dan internet.

Hasil pengabdian masyarakat yang diperoleh adalah kegiatan yang dilaksanakan untuk siswa-siswi SMK Muhammadiyah Parakan Tangerang Selatan adalah kegiatan untuk mengatasi persoalan penyalahgunaan teknologi dalam kegiatan belajar mengajar secara online. Penggunaan teknologi dalam kegiatan belajar mengajar sangat bermanfaat bagi sekolah dan memanfaatkan teknologi komputer maupun internet sebagai media dalam pembelajaran dapat menambah motivasi belajar sisa-siswi serta memudahkan guru dalam membuat modul online.

Ilmu yang diperoleh pada pengabdian masyarakat ini harapannya semakin memberikan wawasan mengenai pemanfaatan teknologi dalam kegiatan belajar mengajar karena penggunaan teknologi dapat mempermudah guru dalam mengajar serta memotivasi siswa-siswi sehingga membuat mereka lebih kreatif dan inovatif dalam kegiatan belajar mengajar pada SMK Muhammadiyah Parakan Tangerang selatan.
\end{abstract}

Kata kunci : Motivasi, Kegiatan Belajar Mengajar, Teknologi

\section{ABSTRACT}

The purpose of Community Service Activities is to carry out one of the Tri Dharma of Higher Education, especially in Pamulang University. In addition, it is hoped that with this community service, the existence of universities can contribute to the development of scientific application to the community.

The method used in community service is conveying material verbally in this implementation. The material in counseling contains how to find out other benefits of technology such as computers and the internet. 


\section{Loyalitas Kreativitas \\ Aldi Masyarakat Kreatif}

P-ISSN 2722-2101, E-ISSN 2722-4201

Program Studi Ekonomi Manajemen Universitas Pamulang

Jurnal LOKABMAS Kreatif Vol.02,No.01,Maret 2021 Hal. 48-54

Email:jurnalkreatif.manajemen@ gmail.com

The results of community service obtained are activities carried out for students of SMK Muhammadiyah Parakan, South Tangerang, which are activities to overcome the problem of technology abuse in online teaching and learning activities. The use of technology in teaching and learning activities is very beneficial for schools and utilizing computer and internet technology as a medium in learning can increase student motivation and make it easier for teachers to create online modules.

The knowledge gained in community service is expected to provide more insight into the use of technology in teaching and learning activities because the use of technology can make it easier for teachers to teach and motivate students so that they are more creative and innovative in teaching and learning activities at SMK Muhammadiyah Parakan Tangerang Selatan.

Keywords: Motivation, Teaching and Learning Activities, Technology

\section{PENDAHULUAN}

Memasuki abad teknologi seperti sekarang ini sangat dirasakan kebutuhan dan pentingnya penggunaan teknologi dalam berbagai bidang salah satunya dalam bidang pendidikan. Perkembangan Teknologi Informasi dan Komunikasi telah memberikan pengaruh terhadap dunia pendidikan, khususnya dalam proses pembelajaran. Komunikasi sebagai media dalam pendidikan dilakukan dengan menggunakan media-media komunikasi. Penggunaan media berbasis komputer ini dapat meningkatkan perhatian dan konsentrasi siswa terhadap pembelajaran, meningkatkan motivasi siswa untuk belajar, menyesuaikan materi dengan kemampuan belajar siswa, mengurangi penggunaan waktu penyampaian materi dan membuat pembelajaran lebih menyenangkan. Komputer juga dapat mengakomodasi siswa yang lamban menerima pelajaran karena ia lebih bisa memberikan iklim yang bersifat afektif dengan cara yang lebih individual, tidak pernah lupa, tidak pernah bosan, sangat sabar dalam menjalankan instruksi seperti yang diinginkan.

$$
\text { Pesatnya perkembangan }
$$

teknologi, memungkinkan pengembangan layanan informasi yang lebih baik dalam suatu institusi pendidikan. Layanan pendidkan lain yang bisa dilakukan melalui TIK yaitu menyediakan materi pelajaran di dalam jaringan (online). Dan materi pelajaran tersebut dapat diakses oleh siapa saja yang membutuhkan. Sebagai contoh pada tingkat pendidikan SMK, implikasi juga sudah mulai dilakukan walaupun belum mampu menjajal dengan implikasiimplikasinya pada tingkatan pendidikan lanjutan. Di SMK rata-rata penggunaan internet hanyalah sebatas fasilitas tambahan dan TIK belum menjadi kurikulum utama yang diajarkan untuk siswa. TIK belum menjadi database utama bagi nilai-nilai, kurikulum, siswa, guru, atau yang lainnya. Namun, prospek untuk masa depan, penggunaan IT di SMK cukup cerah. Selain untuk melayani institut pendidikan secara khusus, dapat juga digunakan untuk dunia pendidikan secara umum di Indonesia. Ada juga layanan sistem internet yang menyajikan kegiatan sistem pendidikan di Indonesia. Situs ini dimaksudkan untuk merangkum informasi yang berhubungan dengan perkembangan pendidikan yang terjadi dan untuk menyajikan sumber umum serta jaringan komnunikasi (forum) bagi administrator sekolah, para pendidik dan para peminat lainnya.

Pengembangan dan penerapan TIK juga bermanfaat untuk pendidikan dalam kaitannya dengan peningkatan 
kualitas pendidikan nasional Indonesia. Salah satu aspeknya adalah kondisi geografis Indonesia dengan sekian banyaknya pulau yang berpencar-pencar dan kontur permukaan buminya yang sering kali tidak bersahabat, biasanya diajukan untuk menjagokan pengembangan dan penerapan TIK untuk pendidikan. TIK sangat mampu dan dijagokan agar menjadi fasiltator utama untuk meratakan pendidikan di Bumi Nusantara sebab TIK mengandalkan kemampuan pembelajaran jarak jauh tidak terpisah oleh ruang, jarak, dan waktu. Teknologi Pembelajaran. Menyediakan fasilitas kerja sama. Komputer awalnya digunakan amat terbatas, hanya untuk keperluan menghitung dalam kegiatan administrasi saja, tetapi sekarang aplikasi komputer tidak saja digunakan untuk komputasi dan pengolahan kata (word processor), tetapi juga sangat memungkinkan untuk sarana pembelajaran.

\section{RUMUSAN MASALAH}

Berdasarkan latar belakang masalah di atas, maka fokus pengabdian masyarakat dibatasi pada ruang lingkup pemanfaatan teknologi dalam memotivasi siswa-siswi dalam kegiatan belajar mengajar. Adapun kegiatannya adalah dengan memberikan edukasi secara visual dan verbal kepada siswa-siswi bahwa penggunaan teknologi dalam kegiatan belajar dapat meningkatkan motivasi siswasiswi dan membuat mereka lebih kreatif dan inovatif dalam belajar.

\section{TUJUAN KEGIATAN}

Dengan dilaksanakannya kegiatan Pengabdian Kepada Masyarakat ini, tujuan yang diharapkan dari akhir kegiatan ini :

1. Memberikanedukasi dan pengarahan kepada siswa-siswi mengenai pemanfaatan teknologi dalam memotivasi proses kegiatan belajar mengajar yang kreatif dan inovatif sebagai media pembelajaran yang menyenangkan.

2. Meningkatkan motivasi belajar siswasiswi sehingga dapat meraih prestasi yang baik dan mampu bersaing dengan sumber daya manusia lainnya.

\section{TINJAUAN PUSTAKA}

\section{Definisi Pengertian Teknologi}

Kata teknologi berasal dari bahasa Yunani, techne yang berarti 'keahlian' dan logia yang berarti 'pengetahuan'. Dalam pengertian yang sempit, teknologi mengacu pada obyek benda yang digunakan untuk kemudahan aktivitas manusia, seperti mesin, perkakas, atau perangkat keras (Rusman dkk, 2012: 78). Di pihak lain berpendapat bahwa teknologi adalah pengembangan, penerapan dan penilaian system-sistem, teknik dan alat bantu untuk memperbaiki dan meningkatkan proses belajar manusia. Disini diutamakan proses belajar itu sendiri disamping alat-alat yang dapat membantu proses belajar itu (Dr. Nasution, 2012: 1). Dalam pengertian yang lebih luas, teknologi dapat meliputi: pengertian sistem, organisasi, juga teknik. Akan tetapi, seiring dengan perkembangan dan kemajuan zaman, pengertian teknologi menjadi semakin meluas, sehingga saat ini teknologi merupakan sebuah konsep yang berkaitan dengan jenis penggunaan dan pengetahuan tentang alat dan keahlian, dan bagaimana ia dapat memberi pengaruh pada kemampuan manusia untuk mengendalikan dan mengubah sesuatu yang ada di sekitarnya. Jadi, teknologi adalah cara dimana kita menggunakan ilmu pengetahuan untuk memecahkan masalah praktis.

Dalam pengertian yang lebih luas, teknologi dapat meliputi: pengertian sistem, organisasi, juga teknik. Akan tetapi, seiring dengan perkembangan dan kemajuan zaman, pengertian teknologi menjadi semakin meluas, sehingga saat ini teknologi 
merupakan sebuah konsep yang berkaitan dengan jenis penggunaan dan pengetahuan tentang alat dan keahlian, dan bagaimana ia dapat memberi pengaruh pada kemampuan manusia untuk mengendalikan dan mengubah sesuatu yang ada disekitarnya. Jadi, teknologi adalah cara dimana kita menggunakan ilmu pengetahuan untuk memecahkan masalah praktis.

\section{Manfaat Teknologi Dalam Pembelajaran \\ Teknologi sangat berkaitan} dengan proses belajar mengajar, dimana teknologi sebagai media yang efektif dan efisien dalam proses belajar mengajar, seperti komputer, laptop, dan piranti lain), aplikasi software dan rangkaian (sebagai contoh internet, wifi, infrastruktur jaringan setempat. Adapun manfaat teknologi dalam pembelajaran yaitu:

1. Menambah informasi

2. Meningkatkan kemampuan belajar

3. Memudahkan akses belajar

4. Materi lebih menarik

5. Meningkatkan minat belajar

\section{Teknologi Sebagai Media Dalam Kegiatan Belajar Mengajar}

Teknologi erat kaitannya dengan perkembangan proses pembelajaran dalam dunia pendidikan, contohnya yaitu komputer atau laptop dan proyektor LCD biasanya digunakan untuk menampilkan gambar pada presentasi di dunia perkuliahan ataupun dalam kegiatan pembelajaran di sekolah terbukti sukses mempermudah kegiatan belajar dan mengajar di sebuah instansi pendidikan. Penggunaan teknologi sebagai media pembelajaran ini jelas akan membuat proses belajar mengajar menjadi efektif dan efisien karena dapat mempermudah guru dalam mendapatkan atau menyampaikan informasi pelajaran, dapat membantu dalam meningkatkan pemahaman siswa, penyajian informasi lebih menarik, memudahkan penafsiran data atau informasi dan mendapatkan informasi dari berbagai referensi dengan mudah.

$$
\text { Kegiatan pembelajaran }
$$

merupakan kegiatan yang paling pokok dalam keseluruhan proses pendidikan. Dengan demikian, pencapaian pendidikan banyak bergantung pada bagaimana proses belajar mengajar yang dirancang dan dijalankan secara profesional. Seperti sekarang ini yang memanfaatkan teknologi khususnya laptop dan internet yang sangat membantu dalam kegiatan proses belajar mengajar.

Jadi dapat dikatakan bahwa teknologi sebagai media berperan penting sebagai alat bantu yang efektif dan efisien dalam proses belajar mengajar.

\section{Motivasi Kegiatan Belajar Mengajar Yang Kreatif dan Inovatif}

Perkembangan teknologi saat ini dapat mempengaruhi motivasi siswa dalam kegiatan belajar mengajar. Setiap siswa memiliki kondisi internal, kondisi internal inilah yang ikut berperan penting dalam aktivitas sehari-hari, salah satu kondisi internal tersebut adalah motivasi atau dorongan. Menurut Edy Sutrisno (2013:109) Motivasi adalah suatu faktor yang mendorong seseorang untuk melakukan suatu aktivitas tertentu, oleh karena itu motivasi sering kali diartikan pula sebagai faktor pendorong perilaku seseorang.

Abraham Maslow mendefinisikan motivasi adalah suatu yang ersifat konstan (tetap), tidak pernah berakhir, berfluktuasi dan bersifat kompleks, dan hal itu kebanyakan meupakan karakteristik universal pada setiap kegiatan organisme. Secara lebih ringkas dapat dikemukakan bahwa motivasi pada dasarnya adalah suatu usaha untuk meningkatkan kegiatan dalam mencapai suatu tujuan tertentu, termasuk didalamnya kegatan belajar. Secara lebih khusus jika orang menyebutkan motivasi belajar yang dimaksudkan tentu segala 
sesuatu yang ditujuakan untuk mendorong atau memberikan semangat kepada seseorang yang melakukan kegiatan belajar untuk memperoleh prestasi yang lebih baik lagi (Purwa Atmaja Prawira, 2012: 319$320)$.

Peranan motivasi yang khas yaitu dalam hal menumbuhkan gairah, merasa senang dan bersemangat untuk belajar, bila seseorang siswa malas belajar, ini berarti pada diri anak tidak terangsang afeksinya untuk melakukan sesuatu, karena tidak memiliki tujuan/kebutuhan belajar. Keadaan semacam ini perlu dilakukan daya upaya yang dapat menemukan penyebabnya dan kemudian mendorong anak tersebut untuk melakukan pekerjaan yang seharusnya dilakukan yaitu belajar, dengan kata lain siswa tersebut perlu diberikan rangsangan agar tumbuh motivasi pada dirinya.

\section{METODE PELAKSANAAN}

Metode kegiatan pengabdian kepada masyarakat ini dibagi menjadi beberapa tahap. Tahap pertama adalah Identifikasi masalah yang dilakukan sebagai langkah awal untuk merumuskan apa saja yang akan dijadikan bahan untuk perancangan sistem dan materi pelatihan dalam kegiatan pengabdian ini.

Tahap berikutnya yaitu melakukan survei lapangan ke SMK Muhammadiyah sebagai tempat dilaksanakannya kegiatan. Kemudian melakukan proses wawancara dan diskusi.

Tahap berikutnya adalah pelaksanaan kegiatan. Kegiatan ini dilaksanakan di tempat mitra, SMK Muhammadiyah Parakan, yang beralamat di Jalan Pendidikan Komp. Ritan Rt. 03 Rw. 09 Desa Parakan Kelurahan Pondok Benda Kecamatan Pamulang Kota Tangerang Selatan, pada hari Kamis 03 Desember 2020 sampai dengan hari Sabtu 05 Desember 2020 mulai pukul 09.00 sampai pukul 11.30
WIB. Kegiatan ini dilakukan dengan memberikan penyuluhan dan pelatihan mengenai pemanfaatan teknologi dalam memotivasi proses kegiatan belajar mengajar kepada siswa-siswi SMK Muhammadiyah Parakan Pamulang Tangerang Selatan. Peserta yang mengikuti kegiatan ini sebanyak 20 orang. Peserta adalah siswa-siswi pilihan dari berbagai jurusan mulai dari kelas $\mathrm{X}$ sampai dengan kelas XII.

Pihak mitra, yaitu SMK Muhammadiyah Parakan menyediakan ruang kegiatan yang memadai dan nyaman. Hal yang perlu diperhatikan yaitu cara mengatur (formasi) tempat duduk. Karena masih berada di masa pandemi, maka peserta dibatasi hanya 20 orang dan untuk tempat duduk serta pelaksanaan kegiatannya disesuaikan dengan protokol kesehatan (duduk diatur agar berjarak, tetap menggunakan masker, mencuci tangan setelah kegiatan, dan protokol kesehatan lainnya).

Tahap berikutnya dalam kegiatan pengabdian kepada masyarakat ini yaitu tindak lanjut dari pelaksanaan kegiatan ini. Pada tahap ini dilakukan penyampaian materi, diskusi atau tanya jawab dan memberikan pelatihan serta pemahaman kaitannya dengan pemanfaatan teknologi dalam memotivasi proses kegiatan belajar mengajar yang kreatif dan inovatif.

Tahap yang terakhir adalah tahap monitoring. Pada tahap ini, dilakukan tracking dan monitaring evaluasi dari rangkaian tahap di atas dimana kepala sekolah menunjukkan hasil progress kegiatan yang sudah dilaksanakan.

Kegiatan pengabdian kepada masyarakat ini bertujuan agar siswa dapat menambah pengetahuan tentang Pemanfaatan Teknologi dalam Memotivasi Proses KBM Yang Kreatif dan Inovatif. 


\section{HASIL DAN PEMBAHASAN}

Hasil pelaksanaan PKM yang dilakukan pada hari Kamis, 03 - 05 Desember 2020 dengan peserta adalah siswa-siswi SMK Muhammadiyah Parakan Pamulang Tangerang Selatan, yaitu kegiatan yang dilaksanakan untuk siswa-siswi SMK Muhamadiyah Parakan Pamulang Tangerang Selatan adalah kegiatan untuk mengatasi akan adanya penyalahgunaan teknologi dalam pembelajaran.Siswa-siswi mendapatkan wawasan dengan materi yang di peroleh dari dosen-dosen manajemen Universitas Pamulang mengenai pemanfaatan teknologi dalam memotivasi proses kegiatan belajar mengajar yang kreatif dan inovatif. Dan respon dari siswasiswi dan guru sangat baik mereka sangat terbantu dengan adanya PKM dari para Dosen Manajemen Universitas Pamulang, menambah pengetahuan dan memotivasi mereka dalam mengatasi permasalahan teknologi yang dapat digunakan sebagai media belajar di sekolah.

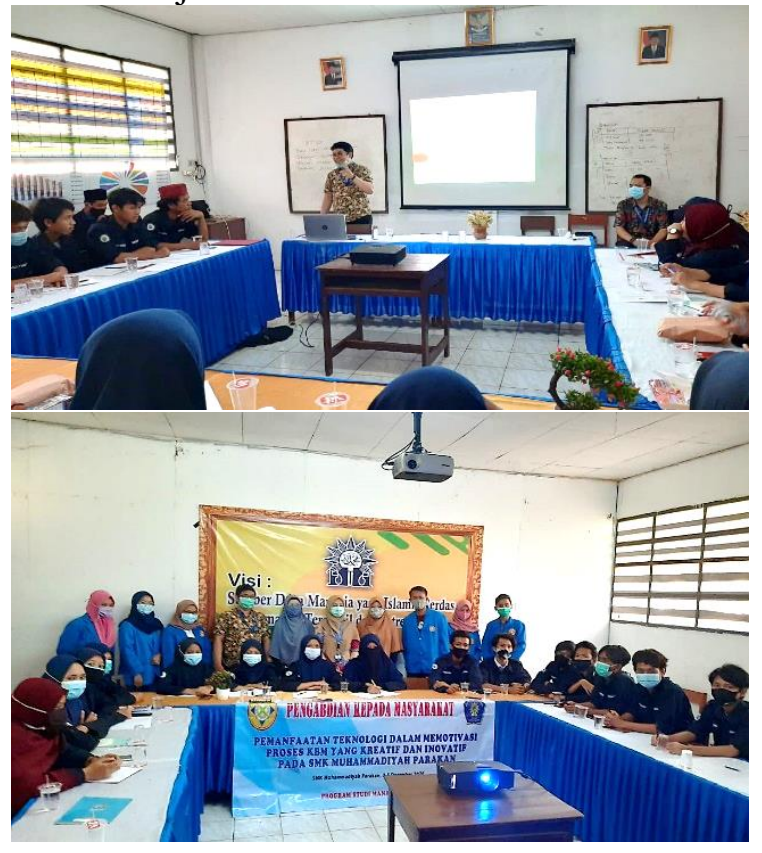

KESIMPULAN DAN SARAN

Kesimpulan
Dari kegiatan PKM ini dapat disimpulkan bahwa siswa-siswi bertambah pengetahuannya perihal akan manfaat teknologi sebagai media dalam kegiatan belajar mengajar dan semakin bertambahnya motivasi serta minat siswa-siswi dalam menggunakan media teknologi (internet, laptop dan lainnya) dalam kegiatan belajar mereka. Dan dengan demikian, judul pemanfaatan teknologi dalam memotivasi proses kegiatan belajar mengajar yang kreatif dan inovatif merupakan PKM yang bertujuan untuk memperkenalkan dan memberikan pengetahuan serta pemahaman kepada siswa-siswi dalam pengetahuan mengenai potensi teknologi sebagai media pembelajaran dan juga merupakan wahana bagi dosen untuk mengabdikan keilmuannya.

\section{Saran}

1. Melatih siswa-siswi dalam penggunaan teknologi sebagai media pembelajaran.

2. Perlu adanya monitoring atau pemantauan yang berkesinambungan terhadap penggunaan teknologi yang digunakan disekolah agar kegiatan belajar mengajar berjalan dengan efektif dan efisien.

3. Pelaksanaan kegiatan PKM ini diharapkan dapat berkembang lebih luas lagi khususnya dalam memanfaatkan teknologi sebagai media pembelajaran sehingga motivasi siswa-siswi dalam kegiatan belajar mengajar meningkat.

\section{DAFTAR PUSTAKA}

Asnawir, Basyiruddin Utsman, 2002, Media Pembelajaran, Jakarta:Ciputat Press.

Dr. Nasution, 2012, Teknologi pendidikan, Jakarta: PT. Bumi Aksara. 
Loyalitas Kreativitas

Aldi Masyarakat Kreatif
P-ISSN 2722-2101, E-ISSN 2722-4201

Program Studi Ekonomi Manajemen Universitas Pamulang Jurnal LOKABMAS Kreatif Vol.02,No.01,Maret 2021 Hal. 4854

Email:jurnalkreatif.manajemen@gmail.com
Pasaribu, V. L. D., Susanti, F., \& Hartuti, E. T. K. (2019). Memotivasi Siswa dan Siswi SMK Letris Indonesia di Dalam Menentukan Pilihan Untuk Melanjutkan Pendidikan Atau Bekerja Setelah Lulus Sekolah. Jurnal Pengabdian Dharma Laksana, 1(2), 161-172.

Pasaribu, V. L. D., Elburdah, R. P., Sudarso, E., \& Fauziah, G. (2020). Penggunaan Manajemen Waktu Terhadap Peningkatan Prestasi Belajar Di SMP Araisiyah. Jurnal ABDIMAS Tri Dharma Manajemen, 1(1), 84-91.

Pasaribu, V. L. D., Oktrima, B., Prabowo, B., Arianto, N., \& Haryoko, U. B. (2020). Progam Pendampingan Dan Penyelenggaraan Pendidikan Anak Pada Usia Dini Terhadap Prestasi Belajar Dilingkungan Rt 020 Rw 009. Kel Giri Peni. Kec Wates. Yogyakarta. Jurnal Lokabmas Kreatif, 1(1), 71-75.
Purwa Atmaja Prawira, 2012, Psikologi Pendidikan dalam Perspektif Baru. Yogjakarta: Ar-Ruzz Media.

Rusman, Deni Kurniawan, Cepi Riyana, 2012, "Pembelajaran Berbasis Tekhnologi Informasi dan Komunikasi”. Jakarta: PT Raja Grafindo.

Sutrisno, Edy, 2014. Manajemen Sumber Daya Manusia Cetakan Ke Enam. Jakarta : Pranada Media Group.

https://smknl-pkp.sch.id/blog/pemanfaatanteknologi-pembelajaran-pada-siswa-belajardari-rumah/

https://yusrintosepuabdikarya.wordpress.co $\underline{\mathrm{m} / 2019 / 07 / 07 / \mathrm{kreatif}-\text { dan-inovatif-dalam- }}$ pendidikan-dan-pengajaran/ https://ilmumanajemenindustri.com/pengert ian-manajemen-persediaan-inventorymanagement-2/ 